\title{
DENDROCHRONOLOGICAL AND RADIOCARBON ANALYSES OF SUBFOSSIL OAKS FROM THE FOOTHILLS OF THE ROMANIAN CARPATHIANS
}

\author{
ZOLTÁN KERN ${ }^{1}$ and IONEL POPA ${ }^{2}$ \\ ${ }^{1}$ Institute for Geological and Geochemical Research, MTA CSFK Lendület $2 \mathrm{ka}$ Palceoclimate Research Group, \\ Budapest, Budaörsi út 45, H-1112, Hungary \\ ${ }^{2}$ National Research and Development Institute for Silviculture Marin Dracea, \\ Silviculture Calea Bucovinei 73 bis, 725100, Câmpulung Moldovenesc, Romania
}

Received 25 April 2016

Accepted 27 July 2016

\begin{abstract}
A set of subfossil macroremains, consisting of 118 oak (Quercus sp.) and 61 elm (Ulmus sp.) trees, was collected at five sites in the foothills of the Eastern Carpathians along the course of the Suceava river. The tree-ring widths of the subfossil samples were measured. Dendrochronological synchronization resulted in five oak chronologies, although each encompassed relatively few (2 to 4) reliably cross-dated series. Radiocarbon analysis was performed on samples from three of the floating chronologies and on an additional single oak sample. Double radiocarbon data from two of the floating chronologies allowed for improved calibration using the wiggle-match estimate of the subfossil oak remains. Radiocarbon evidence highlighted the fact that the subfossil material recovered from the fluvial deposits of the Suceava river may represent a substantial part of the Holocene, from $\sim 700$ to $\sim 7000$ years ago. When temporal distribution of ${ }^{14} \mathrm{C}$ dated sequences from the Suceava black oaks were compared to the calibrated age ranges reported from nearby rivers (Siret, Moldova), deposition events were observed to coincide at around $0.8-0.9 \mathrm{ka}$ cal BP and $\sim 3.7-3.6 \mathrm{ka}$ cal BP. The five presented floating chronologies, and especially the first ${ }^{14} \mathrm{C}$ wiggle-matched tree-ring sequences of Romanian black oaks could become key building blocks in a longer regional oak tree-ring chronology for the Eastern Carpathian region.
\end{abstract}

Keywords: black oak, Holocene, C-14, wiggle-matching, Suceava, Romania.

\section{INTRODUCTION}

Due to their predominant place in the archaeological record and continuous use through historical times, oak (Quercus spp.) chronologies play a central role in European dendrochronological research (Haneca et al., 2009). Owing to the plethora of confirmed findings and the tenacious work of devoted dendrochronologists in many

Corresponding author: Z. Kern

e-mail:kern@geochem.hu tree-ring laboratories, very long oak chronologies have been developed in Central Europe, in e.g. Germany (Becker, 1993; Spurk et al., 2002), Bohemia and Moravia (Kolár et al., 2012), or Poland (Krąpiec, 2001; Gębica and Krąpiec, 2009). Subfossil wood has a great importance in the extension of dendrochronological masterseries well beyond historical times. Among the characteristic environments in which well-preserved old oak samples are regularly found are fluvial sequences, gravel terraces for instance, where a nearby river maintains a continuous groundwater level and buried trees are preserved in an anaerobic environment. Regarding the physical and mechanical properties of subfossil oak wood, it 
was found that its density is highly variable, the dimensional changes are higher (c. double) and mechanical properties (e.g. compression strength, hardness) are approximately $20-50 \%$ lower when compared to recent oak wood (Kolař and Rybniček, 2010). Another characteristic alteration of these oak macrofossils is the blackish colouration, owing to the reaction between tannin and dissolved iron from the groundwater (Krzysik, 1978).

Black oak megafossils are increasingly frequently reported from the Carpathian region, and their utilization as an aid in the reconstruction of alluvial landscape evolution has been initiated very recently in the Eastern Carpathian foreland (Chiriloaei et al., 2012; Gębica et al., 2013; Rădoane et al., 2015). These recent studies, however, did not benefit from the added value of a dendrochronological input, because tree-ring width sequences from the analysed subfossil trunks were not successfully cross-dated.

Regarding the dated oak master chronologies from Romanian territory, these have encompassed living (Nechita and Popa, 2011, 2012) and historical material (Eggertsson and Baboş, 2003; Botár et al., 2008, 2013), but span only a couple of centuries. Though a great chance for the development of a very long record may exist, since a mass expansion of Quercus occurred between 10,200 and 9,500 yrs BP in Romania and the genus has displayed a high abundance throughout the whole Holocene in Romania (Feurdean et al., 2011).

An assessment of long European oak chronologies has pointed out that the southern and central-northern parts of the continent, separated by the Alps, have represented largely distinct tree-ring patterns over historical times (Ważny, 2009). Bridging the core regions of these main European oak dendro-zones was recently designated as a crucial task for future European dendrochronology (Ważny et al., 2014). Prospective achievements have been reported recently from the Central Balkans in the bridging of the oak chronologies of the wider Mediterranean region and north-central Europe (Pearson et al., 2014). However, since the Carpathians, in contrast to the Alps, seem to act as a bridge between the Northern and Southern systems, Romania could also be a key region in this regard (Ważny, 2009).

This paper describes a new Carpathian site, the Suceava river, where numerous black oaks have been collected. The aim of the study was to perform dendrochronological and radiocarbon analyses on the subfossil samples and compare their age distribution to similar findings from two nearby rivers. The presented data provided additional confirmation that these megafossils are very likely available for the entire Holocene in Eastern Carpathian fluvial deposits.

\section{MATERIALS AND METHODS}

\section{Subfossil trunks from the riverside gravel deposit of Suceava river}

Outcropped subfossil logs have been sampled along

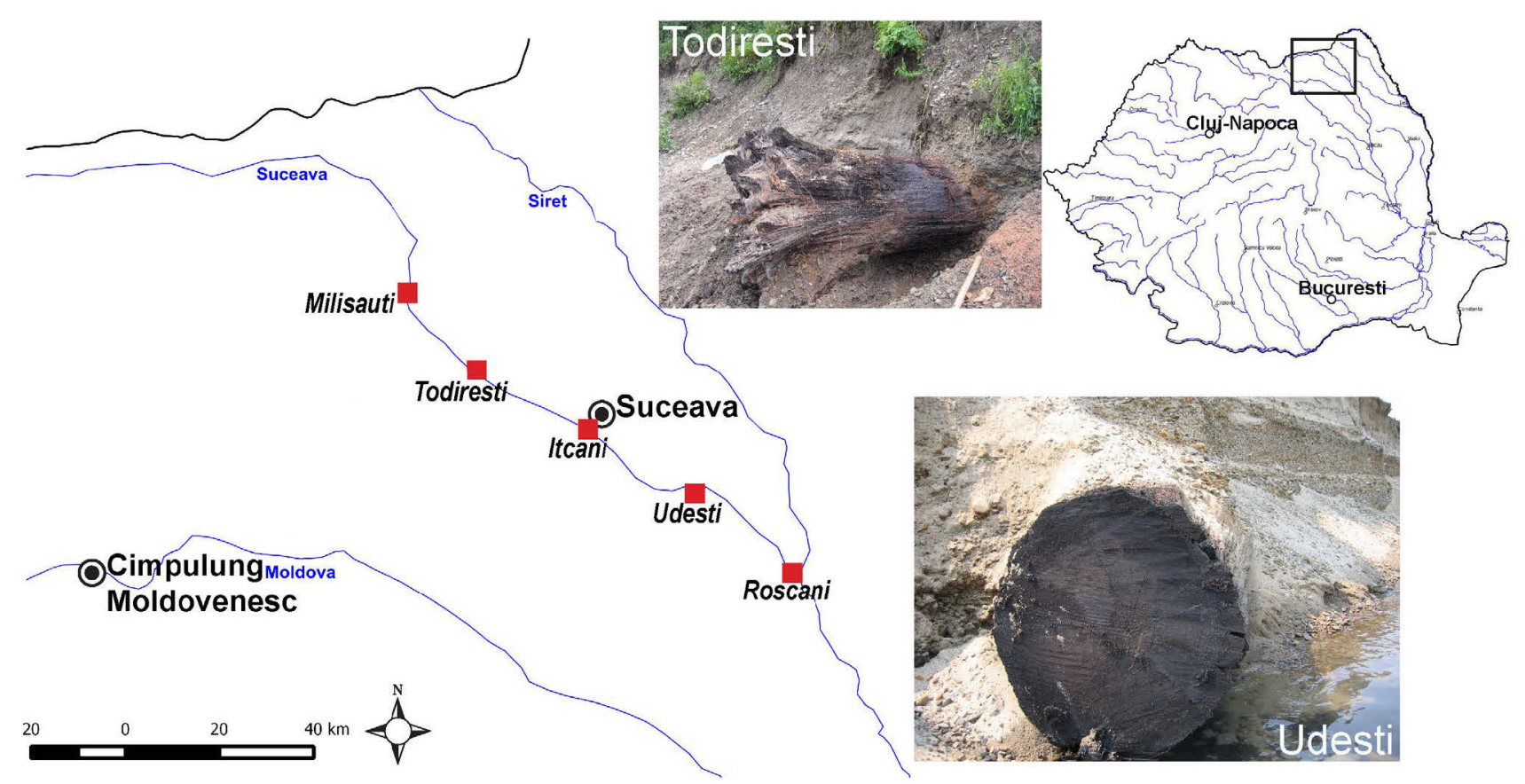

Fig. 1. Location of the collection points (Milisauti, Todiresti, Itcani, Udesti, and Roscani) of fossil trunks along the Suceava river. The rectangle in the inset map shows the location of the enlarged region in Romania. The photos show typical samples: a freshly exposed embedded trunk at the Todiresti site (top) and a sawn section from Udesti (bottom). 
the banks of the Suceava river (Fig. 1) since 2004. A disk sample $(\sim 5-10 \mathrm{~cm}$ thick) was sliced from each trunk using a chainsaw. Cross sections of the dried samples were mechanically sanded until tree-ring boundaries and characteristic wood anatomical details became clearly visible. Genus or occasionally species could be identified based on basic xylem characteristics. At the sampling sites, oak (Quercus sp.), elm (Ulmus sp.) and, very rarely, poplar (Populus sp.) have been observed, though oak samples are by far the most abundant ( $66 \%)$. Poplar samples tend to deform severely after drying, so these samples were not processed. Altogether, 179 samples were collected: 118 oak and $61 \mathrm{elm}$. These latter, however, yielded significantly fewer tree rings (Fig. 2). There were five locations where relative concentrations of subfossil trunks were found (Fig. 1) within a relatively short distance (1-2 km), while an additional 23 samples (14 oaks and 9 elms) represent single findings collected from separate sites along the river during the past $\sim 10$ years. The species composition and the oak dominance are in agreement with other similar European subfossil driftwood assemblages (eg. Kolař and Rybniček, 2011; Carozza et al., 2014; Rădoane et al., 2015), although the relative abundance of elm to oak (1:2) is higher in this Suceava collection. Interestingly, this relative abundance seems to be a robust characteristic of the subfossil assemblages at every site (Fig. 2). As a final decision, due to their dominance and larger number of measurable tree rings, oak samples remained the central focus of the subsequent dendrochronological analysis.

\section{Dendrochronological analysis}

A LINTAB digital-positioning table and TSAP Win 4.68 software (Rinn, 2005) were used to

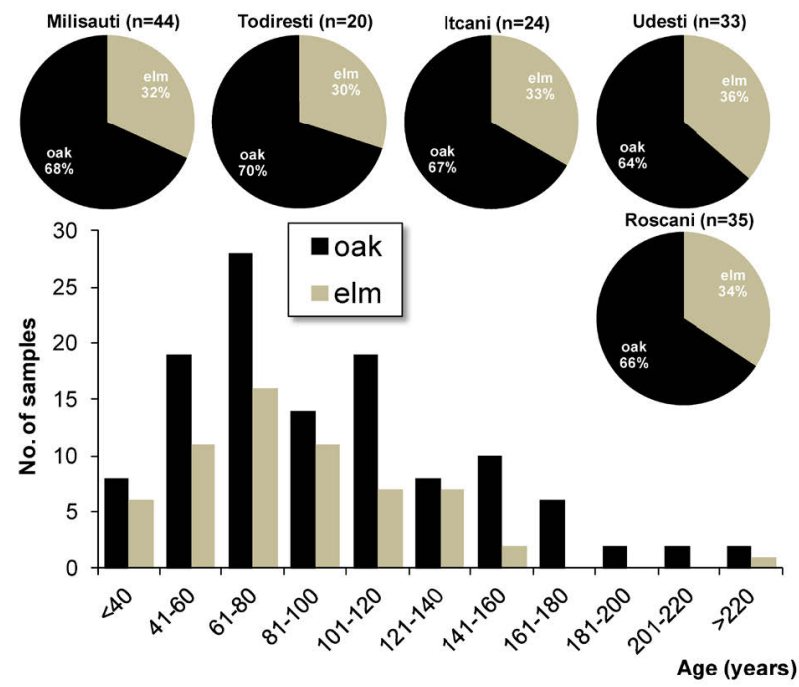

Fig. 2. Age distribution histogram of subfossil oaks and elms from the Suceava river. Pie charts show the species composition at the five collection sites. measure the annual increments to a precision of $0.01 \mathrm{~mm}$, as well as for cross-dating the growth series by means of graphical comparison to each other. For each disk, two radii were measured and the series were checked for the correctness of measurements within the disks. Finally, the mean tree-ring series was determined for each disk and used in the analysis.

Standard dendrochronological statistics, such as percentage of agreement (GLK\%, Eckstein and Bauch, $1969)$ and modified $t$ value ( $t_{\mathrm{BP}}$, Baillie and Pilcher, 1973) were used to evaluate the cross-dating results.

\section{Radiocarbon measurement}

Sample preparation and radiocarbon analysis were performed in the ${ }^{14} \mathrm{C}$ lab of the Hertelendi Laboratory of Environmental Studies, Institute for Nuclear Research, Hungarian Academy of Sciences, Debrecen (Molnár et al., 2012). At an earlier stage of the research, two subsamples from the first successfully cross-dated doublet were analysed by gas proportional counting, while at a later stage four additional samples were analysed using accelerator mass spectrometry. The radiocarbon ages were calculated according to Stuiver and Polach (1977) using the Libby half-life (5568 years). Long-term performance of the Debrecen radiocarbon lab in international intercomparisons proved that the both systems produced excellent data and provided comparable results (Svingor et al., 2016). Although GPC measurement error was slightly greater compared to AMS, but in terms of accuracy, this method cannot stay away from the AMS measurements.

Small blocks containing 2 to 13 tree rings were sliced from the disks (Table 1). Radiocarbon analysis was performed on the extracted $\alpha$-cellulose. For technical details on the applied $\alpha$-cellulose separation method see Szántó et al. (2007).

\section{Gas proportional counting}

Samples were combusted to $\mathrm{CO}_{2}$ in a controlled oxygen stream. Gaseous impurities (such as traces of NOx) and excess $\mathrm{O}_{2}$ unused during combustion were removed by passing the produced $\mathrm{CO}_{2}$ through a hot $\mathrm{Cu}$-furnace. The purified $\mathrm{CO}_{2}$ was trapped in a stainless steel vessel using liquid nitrogen and measured using the gas proportional counting technique (Hertelendi et al., 1989). Correction for fractionation was achieved by measuring the $\delta^{13} \mathrm{C}_{\mathrm{PDB}}$ value using a stable isotope ratio mass spectrometer (Thermo Finnigan Delta ${ }^{\text {plus }}$ XP) in dual-inlet mode.

\section{Accelerator mass spectrometry}

Measured targets were prepared using a sealed-tube graphitization method (Rinyu et al., 2013). The ${ }^{14} \mathrm{C} /{ }^{12} \mathrm{C}$ ratio and ${ }^{13} \mathrm{C} /{ }^{12} \mathrm{C}$ ratio were measured using accelerator mass spectrometry (AMS), with the application of an EnvironMICADAS ${ }^{14} \mathrm{C}$ facility (Molnár et al., 2013a, 2013b). Measurement time and conditions were set to 
Table 1. Sample description with conventional and calibrated ages of wood samples taken from subfossil oak samples from Suceava river gravel terraces. Unmodelled age range shows the simple calibration, while the modelled represents wiggle-matching estimates. A: individual agreement percent of the OxCal wiggle-match model (in case of a single calibration it is not applicable).

\begin{tabular}{|c|c|c|c|c|c|c|c|c|c|c|}
\hline \multirow{2}{*}{$\begin{array}{l}\text { Sample } \\
\text { code }\end{array}$} & \multirow[t]{2}{*}{$n^{a}$} & \multirow[t]{2}{*}{ lab code $b$} & \multirow{2}{*}{$\begin{array}{l}\delta^{13} C_{P D B}{ }^{C} \\
{[ \pm 0.2 \% 0]}\end{array}$} & \multirow{2}{*}{$\begin{array}{c}{ }^{14} \mathrm{C} \text { age } \\
\text { BP }\end{array}$} & \multicolumn{3}{|c|}{$\begin{array}{c}\text { unmodelled } \\
\text { cal BP }(95.4 \%)\end{array}$} & \multicolumn{2}{|c|}{$\begin{array}{c}\text { modelled } \\
\text { cal BP }(95.4 \%)\end{array}$} & \multirow[t]{2}{*}{$A(\%)$} \\
\hline & & & & & from & & to & from & to & \\
\hline SV118 & 5 & Deb-13202 & -24.1 & $5370 \pm 50$ & 6290 & & 6000 & $\begin{array}{cc}6300 & (92.9 \%) \\
9090 & (2.5 \%)\end{array}$ & $\begin{array}{l}6100 \\
6060\end{array}$ & 105.2 \\
\hline SV133 & 13 & Deb-13206 & -23.4 & $5490 \pm 70$ & $\begin{array}{l}6450 \\
6150 \\
6040 \\
\end{array}$ & $\begin{array}{c}(92.8 \%) \\
(2.1 \%) \\
(0.5 \%)\end{array}$ & $\begin{array}{l}60170 \\
6110 \\
6020 \\
\end{array}$ & $\begin{array}{ll}6250 & (92.9 \%) \\
6040 & (2.5 \%)\end{array}$ & $\begin{array}{l}6050 \\
6010\end{array}$ & 74.6 \\
\hline SV41/1 & 3 & DeA-4833 & & $986 \pm 17$ & $\begin{array}{l}940 \\
870\end{array}$ & $\begin{array}{l}(72.7 \%) \\
(22.7 \%)\end{array}$ & $\begin{array}{l}900 \\
800\end{array}$ & 940 & 900 & 109 \\
\hline SV41/2 & 2 & DeA-4470 & & $969 \pm 20$ & $\begin{array}{l}940 \\
870 \\
\end{array}$ & $\begin{array}{l}(40.7 \%) \\
(54.7 \%)\end{array}$ & $\begin{array}{l}890 \\
790 \\
\end{array}$ & 880 & 840 & 64.5 \\
\hline SV159 & 2 & DeA-4471 & & $2260 \pm 23$ & $\begin{array}{l}2350 \\
2250 \\
\end{array}$ & $\begin{array}{l}(44.9 \%) \\
(50.5 \%)\end{array}$ & $\begin{array}{l}2300 \\
2150 \\
\end{array}$ & not ap & plicable & \\
\hline SV191 & 2 & DeA-4531 & & $3390 \pm 34$ & $\begin{array}{l}3810 \\
3720\end{array}$ & $\begin{array}{c}(0.2 \%) \\
(95.2 \%)\end{array}$ & $\begin{array}{l}3800 \\
3560\end{array}$ & not ap & plicable & \\
\hline
\end{tabular}

a number of tree-rings counted in the block of sample used for radiocarbon analysis

b individual laboratory code of the Debrecen radiocarbon lab. 'Deb-' stands for samples measured with gas proportional counting and 'DeA-' for AMS (Molnár et al., 2012)

${ }^{c} \mathrm{AMS}$ measured $\delta^{13} \mathrm{C}$ accounts for the mixed effect of natural and case-sensitive machine fractionation; these data are not therefore shown in the table to avoid confusion

collect at least 200,000 net counts for every single target in the case of a modern sample. The overall measurement uncertainty for a modern sample is $<3 \%$, including normalization, background subtraction, and counting statistics.

The radiocarbon ages were corrected for isotope fractionation using the AMS measured $\delta^{13} \mathrm{C}$, which accounts for both natural and machine fractionation.

\section{Calibration}

The calibration of ${ }^{14} \mathrm{C}$ dates to calendar years was performed using the OxCal v.4.2 (Bronk Ramsey, 2009) program in conjunction with the Northern Hemisphere IntCal13 (Reimer et al., 2013) dataset. Calibrated ages are reported with two standard deviations $(2 \sigma)$.

The so-called wiggle-matching technique (Bronk Ramsey et al., 2001) was employed in the calibration of radiocarbon results obtained from dendrochronologically cross-dated tree-ring sequences using the D_Sequence function of the OxCal v.4.2 (Bronk Ramsey, 2009) program. This means that, thanks to precise a priori knowledge provided by the dendrochronological synchronization, i.e. the exact number of tree-rings between the blocks subjected to radiocarbon measurements, the radiocarbon counting errors are minimized, and this allows for dating with considerably higher accuracy than in case of single radiocarbon measurements (Pearson, 1986).

\section{RESULTS AND DISCUSSION}

\section{Dendrochronological synchronization}

Very few (fewer than 10 samples) had bark or sapwood tree-rings, and these were mainly small size samples. The countable tree rings ranged from 23 to 228 with a mean of 96 tree rings for the black oaks studied. This range and the corresponding distribution pattern (Fig. 2) suggest a younger population compared to the findings usually reported in the broader region (e.g. Gębica and Krąpiec, 2009; Vitas et al., 2014).

Five synchronized groups could be identified, encompassing 2 to 4 samples and spanning from 81 to 228 years (Fig. 3). Unsurprisingly, successfully matched series usually came from samples collected at the same locality. Four series from the Milisauti site were matched into a 218-year long floating chronology (Fig. 3a). Three series, including the two longest ones, were matched into a 228-year long floating chronology from the Roscani collection (Fig. 3b). The only synchronized group containing series from trunks excavated at different sites was the one including SV153\&SV159 from Milisauti and SV310 from Itcani (Fig. 3c), representing a 185-year floating chronology. Finally, two floating chronologies were developed at Itcani near to the city of Suceava. The shorter one contains three series spanning 81 years (Fig. 3d), while a synchronized doublet covers 175 years (Fig. 3e). 
The rather low rate of cross-date success (i.e. 15 matches out of 118 samples: $\sim 13 \%$ ) is far below the Polish standard (Krapiec, 2001), that recently reported from a Belarusian site (Vitas et al., 2014), and from three Croatian sites located along the Sava river and its tributaries (Pearson et al., 2014). Hardly better synchronization success rates, however, have been reported for certain black oak assemblages from the Czech Republic (Kolář and Rybníček, 2011), for instance. Regarding only the series with more than 80 tree-ring data, as Vitas et al. (2014) did, the rate of cross-dating success is higher $(\sim 17.5 \%)$, although it is still far below those cited above.

It is worth mentioning that no series were successfully synchronized from two sites, Todiresti and Udesti. The explanation for Todiresti may be that the age composition of the collected samples at this site was skewed toward the young end. Only four samples were available from Todiresti in which tree ring counts exceeded 100, and even the longest record counted only 133 tree rings. The lack of successful dendrochronological synchronization has also been explained by the small number of tree rings at certain Czech sites (Kolář and Rybníček, 2011). In addition, no series were successfully synchronized representing single trunks collected from separate sites along the river.
These experiences underline the better potential for successful synchronization when larger set of samples can be collected from the same stratigraphic unit, because we can suppose that trunks from the same stratigraphic unit represent the same deposition event, therefore the buried trunks are more likely to be coeval and eroded from a nearby locality.

The occurrence of multiple logs does not guarantee a successful cross-dating, since the redeposition of trunks in alluvia due to lateral migration of a river channel is also well-documented (Kalicki and Krąpiec, 1995). This process can result in subfossil driftwood clusters with very heterogeneous age distribution.

\section{Radiocarbon calibration}

Two ${ }^{14} \mathrm{C}$ results were available from the shorter Itcani chronology (Table 1, Fig. 3d), representing the oldest samples so far retrieved from Suceava fluvial deposits. The calibrated age ranges of SV118 and SV133 largely overlap (Table 1). This provides independent evidence confirming their close age and probably overlapping lifespan. In other words ${ }^{14} \mathrm{C}$ results do not contradict the good synchronization obtained relying on dendrochronological cross-dating statistics.
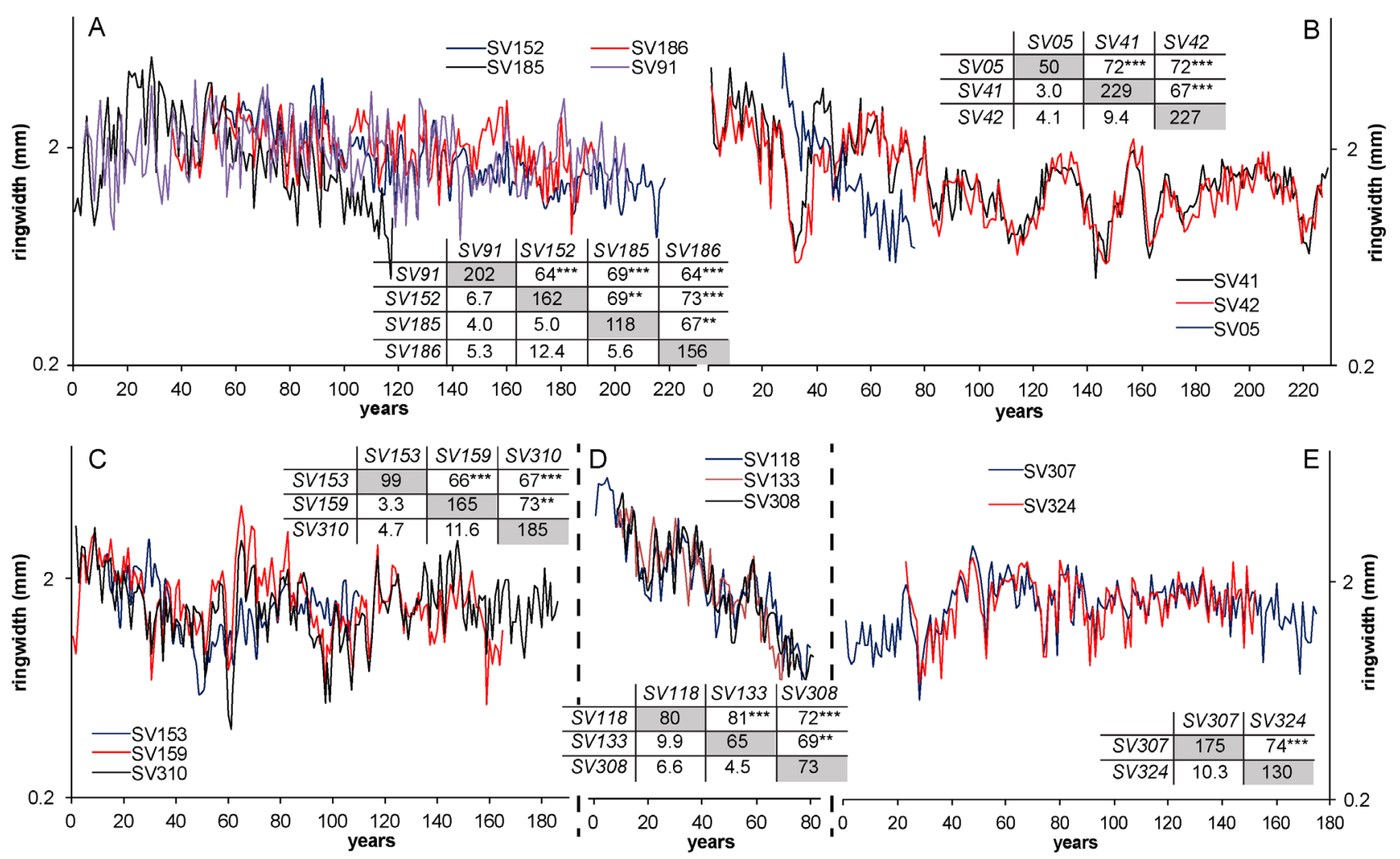

Fig. 3. Synchronized tree-ring width series of subfossil oaks collected along the Suceava river. A: Milisauti, B: Roscani, C: Milisauti \& Itcani, while the series in $D$ and $E$ were obtained from Itcani. Basic synchronization statistics are shown in inset tables. The lengths of the series are given with a gray background along the diagonal, whereas percentage of agreement (GLK\%, Eckstein and Bauch, 1969) and tBP (Baille and Pilcher, 1973) are shown above and below the diagonal, respectively. 
Two ${ }^{14} \mathrm{C}$ results were also available from the Roscani chronology (Table 1, Fig. 3b). In this case, however, the two blocks of tree rings were extracted from the same sample (SV41). Interestingly, the radiocarbon dates place this chronology in the youngest cohort so far collected from the Suceava fluvial deposits.

In addition, the wiggle-matching procedure constrained the single-sample calibrated ranges to a remarkable degree (Table 1). The overall series OxCal agreement indices $\left(\mathrm{A}_{\text {comb }}\right)$ were $84.2 \%$ and $77.9 \%$ for SV118\&SV133 and SV41/1\&2, respectively, and these proved to be satisfactory.

There were an additional 21 and 131 countable tree rings in the crossdated sequences after the blocks removed for radiocarbon analysis in the Itcani (SV118-133308) and Roscani (SV05-41-42) chronologies, respectively. Regarding these additional tree rings, and following the radiocarbon dated blocks, the ${ }^{14} \mathrm{C}$ wiggle-match estimate of the last measured tree ring in the Itcani chronology seems to be $\sim 6230-5990 \mathrm{yr}$ cal BP and in the Roscani chronology $\sim 749-709$ yr cal BP (95.4\% confidence level).

A single ${ }^{14} \mathrm{C}$ result was available from the chronology which included samples from Milisauti and Itcani (Table 1, Fig. 3c). Its calibrated $95.4 \%$ probability range is split up into two intervals with practically equal likelihood: $2350-2300$ yr cal BP or 2250-2150 yr cal BP.

The final ${ }^{14} \mathrm{C}$ date was derived from a single sample from Milisauti (SV191), and its calibrated 95.4\% probability range overwhelmingly points to the $3720-3560 \mathrm{yr}$ cal BP period.

\section{Regional comparisons}

The radiocarbon results provided solid evidence that subfossil oak material -and this is very likely valid for subfossil elm material as well- can be found in the Suceava fluvial deposits back to $\sim 6300$ years ago. In addition, some interesting patterns were observed when the temporal distribution of the Suceava floating oak chronologies were compared with the radiocarbon dates published in studies on late Holocene fluvial activity of two nearby rivers (Chiriloaei et al., 2012; Rădoane et al., 2015), namely the Siret and Moldova (Fig. 4).

There are two periods, $\sim 0.9-0.7 \mathrm{ka}$ cal BP and $\sim 3.7-$ $3.6 \mathrm{ka}$ cal BP, when the deposition of oak megafossils may be presumed to have taken place simultaneously in the three river systems (Fig. 4), suggesting a region-wide event. These are quite remarkable periods within the Holocene population dynamics of Quercus sp. in the region (Feurdean et al., 2011). High resolution pollen records show abrupt changes in oak abundance around $0.8 \mathrm{ka}$. Regarding the second period, a decline has been documented in oak pollen percentages at low elevation Eastern Carpathian sites, while Quercus pollen accumulation rates display a pronounced peak simultaneously in NW Romania (Feurdean et al., 2011).

There are two additional periods around 2.3$2.1 \mathrm{ka} \mathrm{cal} \mathrm{BP}$ and 6.2-6.0 ka cal BP when shared periods of oak trunk deposition can be seen in both the Suceava and Siret (Fig. 4). The first period predates an interval of minor decline in oak pollen percentages in most of the Eastern Carpathian records, while the second broadly coincides with the termination of a period with sustained high oak pollen percentages documented at most of the low elevation sites among the Eastern Carpathian and NW Romanian sites (Feurdean et al., 2011).

In the evaluation of the dendrochronological potential these periods may represent the most promising target periods for future cross-dating trials, since radiocarbon evidence highlights the availability of coeval wood material in the parallel river systems. With regard to its spatial distribution, the Roscani collection seems to be a well suited candidate, since Roscani is situated near the confluence of the Suceava and Siret rivers (Fig. 1), and numerous logs have been found in this section of the river Siret at the nearby Liteni village (Rădoane et al., 2015).

The objective weakness of the preliminary floating Suceava oak chronologies is their low replication. This might be overcome in future investigations by increasing the number of samples taken from sites with similar stratigraphy, and the inclusion of data from nearby rivers (the Moldova and Siret). To compensate for this, one strength might also be mentioned, namely that the terminal tree ring of the 228-year long floating Roscani chronology is within $c a$. 150 years of the earliest tree rings of the longest oak master chronologies from Romania (Eggertsson and Baboş, 2003; Botár et al., 2008). This in turn raises the prospect of the expansion of the Romanian oak master chronologies with this subfossil oak material in the near future.

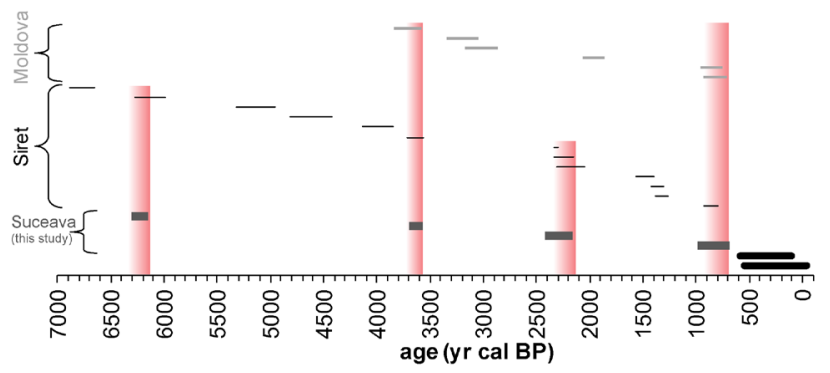

Fig. 4. Temporal distribution of subfossil radiocarbon dated oak megafossils from three rivers from the Eastern Carpathian foothills. The thick gray bars represent the temporal coverage of the three radiocarbon dated floating chronologies and the single SV191 sample from the Suceava river. The chronologies were linked to the median value of the calibrated age range (this study). The thin bars represent the $2 \sigma$ calibrated ranges of subfossil oak samples from Siret (black) and Moldova (gray) rivers (Data from Rădoane et al., 2015). Coinciding deposition events are marked by the shaded vertical stripes. The thick black bars (bottom right) show the temporal coverage of the two longest oak master chronologies available from Romania (Eggertsson and Baboş, 2003; Botár et al., 2008). 


\section{CONCLUSIONS}

The research pointed out that subfossil oak samples from the Suceava river gravel deposits are i) crossdatable, and ii) spread out over time, the last $c a$. 6300 years, with the most recent samples lagging by only a reasonably short time behind the early end date of the regional oak master chronologies. This last statement is important because it suggests good prospects for the expansion of the Romanian oak master chronologies with the aid of these subfossil oak materials in the near future. So far, five floating oak chronologies have been developed from these black oak samples. These encompassed 2 to 4 samples and spanned between 81 and 228 years. Radiocarbon analysis helped to place three of them on a timescale. A useful, although logically expected, methodological experience was that synchronized series usually originated from the same site; in future research it is therefore recommended that special attention be paid to localities with multiple trunks. The presented dataset, and especially the first ${ }^{14} \mathrm{C}$ wiggle-matched tree-ring sequences of Romanian black oaks, may turn out to be a key building block in the construction of a longer regional oak tree-ring chronology. It is foreseen that further samples, the careful selection the best candidates for additional radiocarbon measurements and the employment of the wiggle-matching technique will yield the greatest advances in this work.

The coincident deposition of oak megafossils observed among the Suceava, Siret, and Moldova collections showed remarkable agreement with the reported fluctuations of Holocene oak pollen percentages and pollen accumulation rates from the Eastern Carpathian and NW Romanian sites (Feurdean et al., 2011). This suggests that megafossil material harbours a great potential for its integration with palynological evidence (i.e. microfossil material), contributing to an improved picture of Holocene population dynamics of Quercus sp. in the region.

The rapidly growing subfossil datasets of the Eastern Carpathians (Nechita et al., 2014; Rădoane et al., 2015) and the adjacent forelands (Gebica et al., 2013) invite joint future dendrochronological efforts in the cross correlation of data from these relatively nearby sites; the existence of a shared past climate prevailing over these proximal watersheds may be expected to have resulted in common growth variations in the former oak stands in a way similar to that taking place under modern conditions also. These records have the potential to provide an important pillar to the virtual bridge between the Central European and Mediterranean oak dendrozones.

\section{ACKNOWLEDGEMENTS}

Thanks for the support of the "Lendület" program of the Hungarian Academy of Sciences (LP2012-27/2012). This is contribution No.36 of $2 k a$ Palceoclimatology Re- search Group and No.30 of the Budapest Tree-Ring Laboratory.

\section{REFERENCES}

Baillie MGL and Pilcher JR, 1973. A simple cross-dating programme for tree-ring research. Tree-Ring Bulletin 33: 7-14.

Becker B, 1993. An 11,000-year German oak and pine dendrochronology for radiocarbon calibration. Radiocarbon 35: 201-213.

Bronk Ramsey C, 2009. Bayesian analysis of radiocarbon dates. Radiocarbon 51(1): 337-360.

Bronk Ramsey C, van der Plicht J and Weninger B, 2001. "Wigglematching" radiocarbon dates. Radiocarbon 43(2A): 381-389.

Botár I, Grynaeus A and Tóth B, 2008. "Új” módszer a történeti faszerkezetek keltezéséhez. A dendrokronológiai kutatások kezdetei Erdélyben ("New" way of dating historic wooden structures. The beginnings of dendrochronological research in Transylvania). Transsylvania Nostra II 8, 10-14. (in Hungarian)

Botár I, Grynaeus A and Tóth B, 2013. Dendrochronological analyses and architectural history observations on the unitarian church Ensemble in Dîrjiu, Transsylvania Nostra 2: 2-26.

Carozza JM, Carozza L, Valette P, Llubes M, Py V, Galop D, Danu M, Ferdinand L, David M, Sévègnes L, Bruxelles L, Jarry M and Duranthon F, 2014. The subfossil tree deposits from the Garonne Valley and their implications on Holocene alluvial plain dynamics. Comptes Rendus Géoscience 346(1): 20-27, DOI 10.1016/j.crte.2014.01.001.

Chiriloaei F, Rădoane M, Perşoiu I and Popa I, 2012. Late Holocene history of the Moldova River Valley, Romania. Catena 93: 64-77, DOI 10.1016/j.catena.2012.01.008.

Eckstein D and Bauch J, 1969. Beitrag zur Rationalisierung eines dendrochronologischen Verfahrens und zur Analyse seiner Aussagesicherheit. Forstwissenschaftliches Centralblatt 88(4): 230250

Eggertsson $\mathrm{O}$ and Baboș AD, 2003. Dendrochronological Dating in Maramures with Special Emphases on Objects from the Maramures Museum in Sighetu Marmatiei. Muzeul Maramuresului, Sighetu Marmatiei, Romania, 40-49.

Feurdean A, Tanţău I and Fărcaş S, 2011. Holocene variability in the range distribution and abundance of Pinus, Picea abies, and Quercus in Romania; implications for their current status. Quaternary Science $\quad$ Reviews 30: 3060-3075, DOI 10.1016/j.quascirev.2011.07.005.

Gębica P and Krapiec M, 2009. Young Holocene alluvia and dendrochronology of subfossil trunks in the San river valley. Studia Geomorphologica Carpatho-Balcanica 43: 63-75.

Gębica P, Starkel L, Jacysyn A and Krąpiec M, 2013. Medieval accumulation in the Upper Dniester river valley: the role of human impact and climate change in the Carpathian Foreland. Quaternary International 293: 207-218, DOI 10.1016/j.quaint.2012.05.046.

Haneca K, Čufar K and Beeckman H, 2009. Oaks, tree-rings and wooden cultural heritage: a review of the main characteristics and applications of oak dendrochronology in Europe. Journal of Archaeological Science 36: 1-11, DOI 10.1016/j.jas.2008.07.005.

Hertelendi E, Csongor É, Záborsky L, Molnár J, Gál J, Györffi M and Nagy S, 1989. A counter system for high precision ${ }^{14} \mathrm{C}$ dating. $R a$ diocarbon 31(3): 399-406.

Kalicki T and Krapiec M, 1995. Problems of dating alluvium using buried subfossil tree trunks: lessons from the 'black oaks' of the Vistula Valley, Central Europe. The Holocene 5(2): 243-250, DOI 10.1177/095968369500500213.

Kolař T and Rybniček M, 2010. Physical and mechanical properties of subfossil oak (Quercus sp.) wood. Acta univ. agric. et silvic. Mendel. Brun., 58 No. 4: 123-134

Kolár T and Rybníček M, 2011. Dendrochronological and radiocarbon dating of subfossil wood from the Morava River basin. Geochronometria 38(2): 155-161, DOI 10.2478/s13386-011-0021-x.

Kolář T, Kyncl T and Rybníček M, 2012. Oak chronology development in the Czech Republic and its teleconnection on a European scale. 
Dendrochronologia $\quad 30: \quad 243-248, \quad$ DOI 10.1016/j.dendro.2012.02.002.

Krąpiec M, 2001. Holocene dendrochronological standards for subfossil oaks from the area of Southern Poland. Studia Quaternaria 18: 47-63.

Krzysik F, 1978. Czarna dębina - sposób powstawania i cechy charakterystyczne (Black oakwood - formation and characteristic features). Sylwan 6: 39-41. (in Polish)

Molnár M, Rinyu L, Janovics R, Major I and Veres M, 2012. Az új debreceni C-14 laboratórium bemutatása (Introduction of the new AMS C-14 laboratory in Debrecen). Archeometriai Mühely 9:147160.

Molnár M, Janovics R, Major I, Orsovszki J, Gönczi R, Veres M, Leonard AG, Castle SM, Lange TE, Wacker L, Hajdas I and Jull AJT, 2013a. Status report of the new AMS C-14 sample preparation lab of the Hertelendi Laboratory of Environmental Studies, Debrecen, Hungary. Radiocarbon 55: 665-676.

Molnár M, Rinyu L, Veres M, Seiler M, Winacker L and Synal H.-A, 2013b. EnvironMICADAS: a mini 14C-AMS with enhanced gas ion source interface in the Hertelendi Laboratory of Environmental Studies (HEKAL), Hungary. Radiocarbon 55: 338-344, DOI $10.2458 /$ azu js rc. 55.16331 .

Nechita C and Popa I, 2011. Dendrochronology of oak species in Vaslui region, tree - ring growth responses to climate. Analele Universității din Oradea, Fascicola Protecția Mediului 17: 503-510.

Nechita C and Popa I, 2012. The relationship between climate and radial growth for the oak (Quercus robur L.) in the western plain of Romania. Carpathian Journal of Earth and Environmental Sciences 7(3): 137-144.

Nechita C, Rădoane M, Chiriloaei F, Rădoane N, Popa I, Roibu C and Robu D, 2014. Subfossil oaks from alluvial deposits and their role in past fluvial activities analysis: case study East Carpathian rivers, Romania. In: Mindrescu M. (Ed.) Late Pleistocene and Holocene climatic variability in the Carpathian-Balkan Region 2014, Georeview Abstracts volume, Stefan cel Mare University Press, Suceava, 107-110.

Pearson GW, 1986. Precise calendrical dating of know growth-period samples using a "curve fitting" technique. Radiocarbon 28: 292299.

Pearson CL, Ważny T, Kuniholm PI, Botić K, Durman A and Seufer K, 2014. Potential for a new multimillennial tree-ring chronology from subfossil Balkan river oaks. Radiocarbon 56(4): S51-S59, DOI 10.2458/azu_rc.56.18342.

Rădoane M, Nechita $\bar{C}$, Chiriloaei F, Rădoane N, Popa I, Roibu C and Robu D, 2015. Late Holocene fluvial activity and correlations with dendrochronology of subfossil trunks: case studies of northeastern Romania. Geomorphology 239: 142-159, DOI 10.1016/j.geomorph.2015.02.036.

Reimer PJ, Bard E, Bayliss A, Beck JW, Blackwell PG, Bronk Ramsey C, Grootes PM, Guilderson TP, Haflidason H, Hajdas I, Hatte C, Heaton TJ, Hoffmann DL, Hogg AG, Hughen KA, Kaiser KF, Kromer B, Manning SW, Niu M, Reimer RW, Richards DA, Scott EM, Southon JR, Staff RA, Turney CSM and van der Plicht J, 2013. IntCal13 and Marine13 radiocarbon age calibration curves 0-50,000 years cal BP. Radiocarbon 55(4): 1869-1887.

Rinyu L, Molnár M, Major I, Nagy T, Veres M, Kimák Á, Wacker L and Synal HA, 2013. Optimization of sealed tube graphitization method for environmental C-14 studies using MICADAS. Nuclear Instruments and Methods in Physics Research Section B: Beam Interactions with Materials and Atoms 294: 270-275, DOI 10.1016/j.nimb.2012.08.042.

Rinn F, 2005. TSAP reference manual. 110 pp.

Spurk M, Leuschner HH, Baillie MGL, Briffa KR and Friedrich M, 2002. Depositional frequency of German subfossil oaks climatically and non-climatically induced fluctuations in the Holocene. The Holocene 12: 707-715, DOI 10.1191/0959683602hl583rp.

Stuiver M and Polach HA, 1977. Reporting of C-14 data - Discussion. Radiocarbon 19: 355-363.

Szántó Zs, Kertész R, Morgós A, Nagy D, Molnár M, Grabner M, Rinyu L and Futó I, 2007. Combined techniques to date the first Turkish bridge over the river Tisza, Hungary. Radiocarbon 49: 515-526.

Svingor É, Mogyorósi M, Futó I, Veres M, Molnár M and Rinyu L, 2016. Overview of the international intercomparisons of the Gas Proportional Counting (GPC) C-14 Laboratory, Debrecen, Hungary. Archeometriai Mühely 13(1): 9-18.

Vitas A, Mažeika J, Petrošius R and Pukienė R, 2014. Radiocarbon and dendrochronological dating of Sub-fossil oaks from Smarhon riverine sediments. Geochronometria 41(2): 121-128, DOI 10.2478/s13386-013-0150-5.

Ważny T, 2009. Is there a separate tree-ring pattern for the Mediterranean oaks. Tree-Rings, Kings, and Old World Archaeology and Environment: Papers Presented in Honor of Peter Ian Kuniholm, $41-50$.

Ważny T, Lorentzen B, Köse N, Akkemik Ü, Boltryk Y, Güner T, Kyncl J, Kyncl T, Nechita C, Sagaydak S and Vasileva JK, 2014. Bridging the gaps in tree-ring records: creating a high-resolution dendrochronological network for Southeastern Europe. Radiocarbon 56(4): S39-S50, DOI 10.2458/azu rc.56.18335. 